\title{
Mineral Trioxide Aggregate as Material of Choice in Endodontic Therapy
}

\author{
Vukoman Jokanović1, Božana Čolović1, Slavoljub Živković , Vesna Živojinović3, Dejan Marković3 \\ IInstitute for Nuclear Sciences "Vinča", Belgrade, Serbia; \\ ${ }^{2}$ Clinic for Restorative Dentistry and Endodontics, School of Dentistry, University of Belgrade, Belgrade, Serbia; \\ ${ }^{3}$ Clinic for Preventive and Pediatric Dentistry, School of Dentistry, University of Belgrade, Belgrade, Serbia
}

\begin{abstract}
SUMMARY
Mineral trioxide aggregate (MTA) is a material with broad indications in endodontics. Currently, this material is used for pulp capping, pulpotomy, as apical barrier in teeth with necrotic pulp and open apex, and in the treatment of various root canal perforations. By comparing the biological response of pulp tissue capped with calcium hydroxide and MTA, the superiority of MTA has been indicated. The bridge of hard tissue formed under MTA prevented the irritation of pulp. Histological studies of pulpotomy in dog teeth have shown after 120 days a hard tissue without necrosis formed under MTA. MTA is also the material of choice for retrograde root canal obturation and lateral perforation. Meta analysis of published papers on MTA in recent years indicated the great clinical success of this material which ensured a good canal seal and superior biocompatibility. It is the only material for retrograde root canal obturation that encourages tissue regeneration. Studies have also shown that MTA has inductive and conductive properties for hard tissue as well as the ability to release ions in a liquid medium. The main disadvantage of MTA is related to its color, the presence of iron and mangan ions, the difficulties in maintaining the characteristics of material during time, absence of solvent for this material and the difficulty for its removal after crosslinking.
\end{abstract}

Keywords: mineral trioxide aggregate; direct pulp capping; retrograde surgery; clinical application

\section{INTRODUCTION}

Mineral trioxide aggregate (MTA) is a material with broad indications in endodontics. It is used in the treatment of various perforation of the root canal, pulpotomy and treatment of vital pulp as well as an apical barrier in teeth with necrotic pulp, and open apex. In contact with synthetic tissue fluids, MTA forms hydroxyapatite crystals which act as a base for the formation of calcified structures after application of this material $[1,2]$.

MTA was primarily developed as material for pulp capping, pulpotomy or as material for the formation of apical barrier in teeth with immature roots, as well as material for retrograde root canal obturation. In studies on animal models (primary teeth model in pig) related to the vital pulp therapy, MTA, $\beta$-tricalcium phosphate and portland cement $(\mathrm{PC})$ caused similar pulp reaction.

Numerous investigations on direct pulp capping in permanent teeth were performed in order to evaluate formation, quality and thickness of calcified bridge, presence of inflammatory cells, and the efficiency of pulp protection as important criteria for assessing pulp vitality after the treatment. Comparative analysis of MTA and $\mathrm{Ca}(\mathrm{OH})_{2}$ as materials for direct pulp capping, pointed to the important differences. After application of MTA, the appearance of calcified bridge was observed after one week. Pulp was not inflamed and in all cases after five months there was a calcified bridge formation. In contrast, pulps capped with $\mathrm{Ca}(\mathrm{OH})_{2}$ showed the presence of inflammation and significantly lower degree of calcified bridge formation. In the experiments on dogs it was found that after pulp capping with MTA osteodentinal structure could be formed after two weeks only. The formation of bridge occurs is in two phases. During the first two weeks the osteodentine matrix is formed. After three weeks a complete layer of reparative dentin is created. Better results are found after pulp capping with MTA as compared to products based on calcium hydroxide in dogs' teeth $[1,2]$.

In the study of maxillary molars in mice, Andelin et al. [3] compared MTA with bone morphogenetic protein -7 (BMP-7) as material for pulp capping. The samples were stained immunohystochemically to identify the dentin sialoprotein (DSP) using functional marker for odontoblasts. Two weeks later all teeth where pulps were capped with MTA showed formation of hard tissue very similar to tertiary dentin.

Comparison of biological response of the pulp to $\mathrm{Ca}(\mathrm{OH})_{2}$ and MTA indicates superiority of MTA because MTA forms hard tissue bridge that prevents pulp irritation. Research on osteodentin deposition, cell proliferation and the appearance of immunoreactive cells similar to odontoblasts showed that a thin layer of necrosis with inflammatory cells was formed first (after one day), and after seven days a calcified bridge was formed. Another study on maxillary molars in mice showed the presence 
of calcified bridge in all samples, five hours after pulp capping.

In animal studies, mechanically exposed pulp of hiperglycemic rats showed greater degree of inflammation and slower formation of dentin bridge as compared to normal rats after pulp capping with MTA. SEM and TEM studies on dogs have also clearly indicated the formation of crystal structures one week after pulp capping $[4,5]$.

Using EDS analysis, researchers found that under MTA there is a smaller amount of calcium than in the previously formed ortodentin. This study indicates that the calcified bridge is mainly composed of calcium and phosphorus, although the MTA is mainly composed of Ca and Si.

Research on the effect of pulpotomy and five different agents done by Shayegan et al. [6] on deciduous swine teeth have shown significant advantages of MTA in relation to inflammation, calcified bridge formation and protection of the remaining tooth pulp from Formocresol (FC), a compound that contains formaldehyde, cresol, glycerin, water and ferric sulphate. Histological studies of pulpotomy in permanent teeth of rats and mice, which compared MTA, $\mathrm{PC}, \mathrm{Ca}(\mathrm{OH})_{2}$, bioactive glass and fero sulfate, have shown similar results for the MTA and PC. Similar studies on maxillary molars of rats have shown that after pulpotomy using MTA, the complete dentin bridge was observed after four weeks only. When pulpotomy was performed on dog teeth using MTA, hard bone tissue without necrosis of the pulp was formed after 120 days [7]. In comparison to $\mathrm{Ca}(\mathrm{OH})_{2}$, when MTA was used the loss of healthy tissue of the pulp was less. It was attributed to higher initial $\mathrm{pH}$ values, and poor sealing of the pulp with products based on calcium hydroxide. The absence of hard barriers below the $\mathrm{Ca}(\mathrm{OH})_{2}$ was observed as well as a discrete inflammatory response of pulpal tissue.

SEM investigation and analysis using X-rays showed that the calcified material under the MTA was more tubular than below calcium hydroxide and AEDB $[3,4,5,8]$.

\section{MTA AS MATERIAL FOR RETROGRADE FILLING OF THE ROOT CANAL}

The first study in which MTA was used as material for retrograde filling of root canals in dogs was performed by Torabinejad et al. [9]. He showed that MTA promoted the formation of cement in 23\% of the samples after 2-5 weeks, and in more than $80 \%$ of cases formation of cement was observed 10-18 weeks after periapical surgery. In contrast, no retrograde filling with amalgam showed the deposition of cement. Comparing MTA with amalgam and Super EBA (Super EBA is cement based on zinc oxide-eugenol, which is composed of $32 \%$ eugenol and 68\% ethoxy benzoil acid), it was found that MTA showed better results from the standpoint of polymorphonuclear infiltration, bone maturation and the formation of cement $[7,10]$.

In contrast to these histological findings, Bernabe et al. [11] showed no significant differences between used materials 180 days after surgery in non vital teeth. In addition, ZOE (zinc oxide-eugenol) had a significant negative impact on the apical healing as compared to the other tested materials. MTA is the only proven for hard tissue deposition in direct contact with the material for root canal filling [12].

\section{MTA AS THE MATERIAL FOR THE TREATMENT OF LATERAL PERFORATION}

Pitt Ford et al. [13] first used MTA in the treatment of lateral perforation. In these studies it was shown that, unlike the amalgam, the cement was formed under the MTA in majority of treated teeth. It was noted that untreated perforations became contaminated and the effect of MTA was significantly reduced. Compared with Super EBA, where there was no formation of cement even after six months, in all samples done with MTA, the formation of cement was observed. The study of Noetzel et al. [14] demonstrated similar results. When MTA was compared to tricalcium phosphate cements, it was observed that MTA showed significantly less inflammation and more bone formation $[9,11]$.

Based on numerous studies where MTA was compared to other materials for the repair of perforations, it was confirmed that MTA provides the best histological results. Results of MTA were significantly better as compared to Sealapex. In samples with MTA after 180 days the formation of cement and no signs of inflammation were observed $[9,11]$.

\section{MTA AS AN APICAL BARRIER IN TEETH WITH NECROTIC PULP AND IMMATURE ROOTS}

Shabahang et al. [15] in their studies on dog teeth with immature roots caused periapical lesions and then used osteogenic protein-1, MTA and $\mathrm{Ca}(\mathrm{OH})_{2}$ as an apical barrier. Teeth with MTA showed a higher prevalence of apical closure and significantly less inflammation than the other two groups. On the other hand, in experiments on monkey's teeth with infected root canal and open apex, significant benefit of MTA was observed as compared to $\mathrm{Ca}(\mathrm{OH})_{2}$. After 90 days of obturation, canals filled with MTA had higher amounts of hard tissue formed and the least inflammation. Results of Felippe et al. [16] in similar studies, have revealed that MTA and $\mathrm{Ca}(\mathrm{OH})_{2}$ did not show major differences in teeth with immature root and infected and non infected canals, from the standpoint of the apical barrier formation, bone resorption or the presence of microorganisms. These studies have shown that MTA can be used as an apical barrier in teeth with necrotic pulp and open apex without prior treatment with $\mathrm{Ca}(\mathrm{OH})_{2}[13,14,15,17]$.

\section{MTA AS POTENTIAL MATERIAL FOR ROOT CANAL OBTURATION}

Holland et al. [18] compared MTA as the material for root canal obturation with root canal sealers based on GIC (Ketac-Endo) in dog teeth. His results showed six months 
after obturation with MTA the main root canal closed, the formation of new cementum and the absence of inflammatory cells. In contrast, GIC caused just a partial closure of the main root canal and a mild inflammatory reaction around the root tip. The authors also explored the impact of quality of obturation and the response of apical and periapical tissue after root canal obturation with MTA. Studies have shown that MTA can be used for obturation, but overfilling can have harmful effects on periapical tissue [16].

\section{ANIMAL STUDIES ON OTHER TYPES OF MTA}

Angelus MTA (AMTA) is another type of MTA and consists of $\mathrm{SiO}_{2}, \mathrm{~K}_{2} \mathrm{O}, \mathrm{Al}_{2} \mathrm{O}_{3}, \mathrm{Na}_{2} \mathrm{O}, \mathrm{Fe}_{2} \mathrm{O}_{3}, \mathrm{SO}_{3}, \mathrm{CaO}, \mathrm{MgO}$ and $\mathrm{Bi}_{2} \mathrm{O}_{3}$. Comparing the effects of MTA and AMTA used for pulpotomy in dog teeth, the formation of calcified bridge was evident in both materials. However, in comparison to $\mathrm{Ca}(\mathrm{OH})_{2}$, after 180 days the difference was not significant. Holland et al. [18] used MTA mixture with polypropylene or distilled water as material for root canal obturation in dogs. The effect of overfilling of the root canals was also examined. Both compounds showed similar biological response but better results were observed in root canals obturated with MTA. Bortoluzzi et al. [19] compared the mixtures of MTA powder with $10 \% \mathrm{CaCl}_{2}$ or distilled water used in pulpotomy in dog teeth. After 90 days both materials showed satisfying results on hard tissue formation, but also moderate chronic inflammation and angioblastic proliferation [16].

\section{CLINICAL APPLICATION OF MTA}

Clinical trials are of great importance for the evaluation of material effectiveness and suitability for the application in clinical practice. MTA is a material of choice for retrograde obturation of the root canal, pulp capping, pulpotomy, formation of apical barrier in teeth with necrotic pulp and open apex, perforation therapy and apexification. Several papers studied the use of MTA as pulp capping material and confirmed its effectiveness in the treatment of pulpotomy $[18,20]$.

In a series of clinical studies it has been shown that MTA could be successfully applied for pulp capping in deciduous molars (radiographic success after 24 months was observed after use of MTA and $\left.\mathrm{Ca}(\mathrm{OH})_{2}\right)$. The application of MTA in pulpotomy was more efficient as compared to Formocresol (FC) or Formocresol mixed with $\mathrm{ZnO}$ and eugenol and application of diodes laser. After 12 months the clinical, radiographic and histological studies have shown the superiority of MTA as compared to FC.

In their clinical report O'Sullivan and Hartwell [21] confirmed the efficacy of MTA as material for obturation in primary molars. Ex vivo study was performed using third molars with immature root apex embedded in cell culture medium immediately after extraction. They covered exposed pulp with MTA or $\mathrm{Ca}(\mathrm{OH})_{2}$. Immunohistochemical analysis of pulp capped with MTA showed mineralization in just one day, while with $\mathrm{Ca}(\mathrm{OH})_{2}$ mineralization was not registered. However, after 14 and 28 days in both groups of materials similar degree of mineralization was detected $[20,21,22]$.

In the study on 14 intact human third maxillary molars (which required extraction) the pulp was exposed and capped with MTA or $\mathrm{Ca}(\mathrm{OH})_{2}$. Histological analysis of teeth in different time intervals showed the formation of dental bridge and mild chronic inflammation in two months. Samples with $\mathrm{Ca}(\mathrm{OH})_{2}$ showed the presence of irregular and thin dentinal bridges with associated necrosis, hyperemia and inflammation after three months. The authors concluded that in the treatment of mechanically exposed pulp, MTA was more successful material than $\mathrm{Ca}(\mathrm{OH})_{2}$. Clinical research on human third molars without caries related to MTA and $\mathrm{Ca}(\mathrm{OH})_{2}$ showed significant differences in clinical symptoms, surface and depth of inflammatory cells, pulp vitality and the formation of dentin bridge. Molars that had reversible pulpitis and were treated with MTA showed the treatment success in $93 \%$ of cases after 24 months. All samples where MTA was used showed dentin bridge formation while the formation of dentin bridge after capping with $\mathrm{Ca}(\mathrm{OH})_{2}$ occurred in $60 \%$ of cases only. Histological analysis showed that in MTA samples after one week no inflammation was detected and after one month hard tissue was fully formed. Tissue under $\mathrm{Ca}(\mathrm{OH})_{2}$ was less consistent, firm and with incomplete calcified bridge with acute inflammation even after three months [23-26].

In all studies when $\mathrm{Ca}(\mathrm{OH})_{2}$ was used as pulp capping material more serious inflammation was detected as compared to MTA. Qudeimat et al. [27] studied the effect of material on 28 teeth with caries. The procedure consisted of caries removal and 2-4 $\mathrm{mm}$ of the pulp from the root canal and capping the pulp with MTA. Normal response to vitality tests had $79 \%$ of the teeth [23-26]. Out of 23 symptomatic teeth obturated with MTA constant pain was registered in one single case. Therefore, the use of MTA in pulpotomy of permanent teeth is justified.

In the review paper where the concept of modern endodontic surgery was presented, Kim and Kratchman [28] showed that MTA is the most compatible material for retrograde root canal obturation and can be recommended as high-quality option in endodontic surgery. An interesting approach is provided by one study that combined endodontic and periodontal treatment approach using MTA. In the study done on 276 teeth with retrograde obturation using MTA, Saunders [29] demonstrated clinical and radiographic success in $88.8 \%$ of cases after $4-72$ months.

Meta analysis of 30 papers published in recent years indicates great clinical success of MTA, which provided good sealing, superior biocompatibility and was the only material for retrograde filling of the root canals (as compared to amalgam, zinc oxide-eugenol (IRM) and Super-EBA) which stimulated the tissue regeneration. In addition some studies showed that MTA can be used in the treatment of lateral perforations [26, 30,31,32].

During the period of 6-12 months, lateral perforation in $82 \%$ of the cases was successfully healed after application of MTA. 
In order to prevent extrusion, as one of the disadvantages of MTA, some authors proposed the addition of collagen. Treatment of the teeth with immature root apex and necrotic pulp is a particular challenge for a dental practitioner. Formation of apical barrier with MTA is much faster than with $\mathrm{Ca}(\mathrm{OH})_{2}$. The application of MTA increased the success of necrotic pulp treatment with immature roots significantly (in $81-94.1 \%$ of cases). The success of the treatment was not influenced by age, gender, initial pre-treatment, the presence of lesion and time after the treatment completition [32, 33].

Statistics show that $86.3 \%$ of pediatric specialists think that the treatment of incisors with immature roots and necrotic pulp with MTA is acceptable method because it provides the regenerative potential to the pulp.

In several clinical studies in deciduous and permanent teeth, a successful surgical and conservative treatment of teeth with external and internal resorption using MTA was registered. MTA was proved successful in the treatment of lateral perforation, horizontal root fracture, root canal obturation, treatment of teeth with immature roots and treatment of internal and external root resorption etc. [26, 30-33].

\section{THE MECHANISM OF ACTION OF MTA}

One of the characteristics of bioactive materials is ability to form the structure similar to apatite on their surface when they come in contact with physiological fluids in vivo or with simulated body fluids in vitro. The formation of apatite is a common feature of biomaterials containing calcium silicate. MTA is bioactive material which consists mainly of calcium and the silicate. Research shows that it has conductive and inductive properties on the formation of hard tissue. At the same time, numerous studies show the release of different ions from the MTA in a liquid medium.

Sarkar et al. [34] obturated root canals with MTA and kept them in PBS for two months with constant monitoring of released ions $\mathrm{Ca}, \mathrm{Si}, \mathrm{Bi}, \mathrm{Fe}, \mathrm{Al}$ and $\mathrm{Mg}$. Optical and SEM microscopy of root resection showed the presence of layer between the MTA and root canal walls. This structure was analyzed with EDS and revealed that this layer consisted of atoms of $\mathrm{Ca}, \mathrm{P}$ and $\mathrm{O}$ and it was very similar to hydroxyapatite. The authors believe that the $\mathrm{HA}$ may continuously release $\mathrm{Ca}$ ions and $\mathrm{PO}_{4}{ }^{3-}$ similarly to the process characteristic for bone metabolism. This phenomenon also increases the sealing ability of MTA and enhances regeneration and remineralization of hard tissues. These results suggested that biocompatibility, sealing ability of MTA as well as dentogenic activity are the consequences of physicochemical reactions between MTA and body fluids during the formation of hydroxyapatite $[35,36]$.

Many animal studies have confirmed that hard structure formed on the interface of the pulp and MTA, is in fact the component of hydroxyapatite. Small amount of $\mathrm{Si}$ and P was found in MTA crystals. The porosity of MTA is a potential drawback of MTA and can lead to the penetra- tion of bacteria and their metabolic products. The formation of this layer provides chemical bond of MTA to dentin wall and could be a key feature of this material. Current studies show that carbonated hydroxyapatite formed from MTA also exhibit bioactivity of MTA. Carbonate hydroxyapatite is the mineral phase of hard tissues such as bone, cementum and dentin and is known as biological apatite. Hydroxyapatite is formed on MTA after one hour only and MTA is completely covered after five days.

According to studies, the formation of crystals within the collagen fiber promotes the reaction between MTA and dentin by forming the appropriate chemical bond. The concentration of growth factors also plays a significant role in the formation of hard tissue. For example, high concentrations of TGF- $\beta 1$ cause apoptosis and reduction of dentin fosfosialoprotein rather than to have a positive effect on healing tissue. Some researchers assume that the production of TGF- $\beta 1$ is a positive effect of bioactive mate-

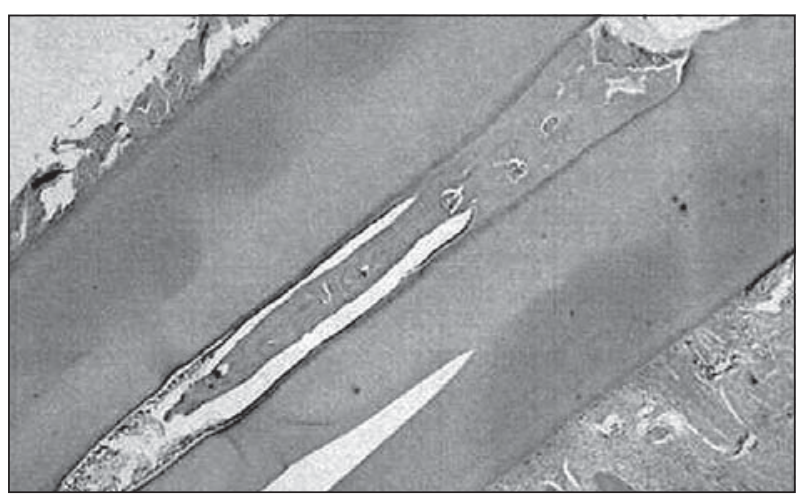

Figure 1. Vital pulp tissue and newly formed hard tissue which obliterates the root canal after use of MTA for pulpotomy in canine in the upper jaw (magnification 10/0.25, 160\%)

Slika 1. Vitalno pulpno tkivo i novoformirano tvrdo tkivo posle pulpotomije očnjaka sa MTA u gornjoj vilici koje obliteriše kanal korena zuba (uvećanje 10/0.25; 160\%)

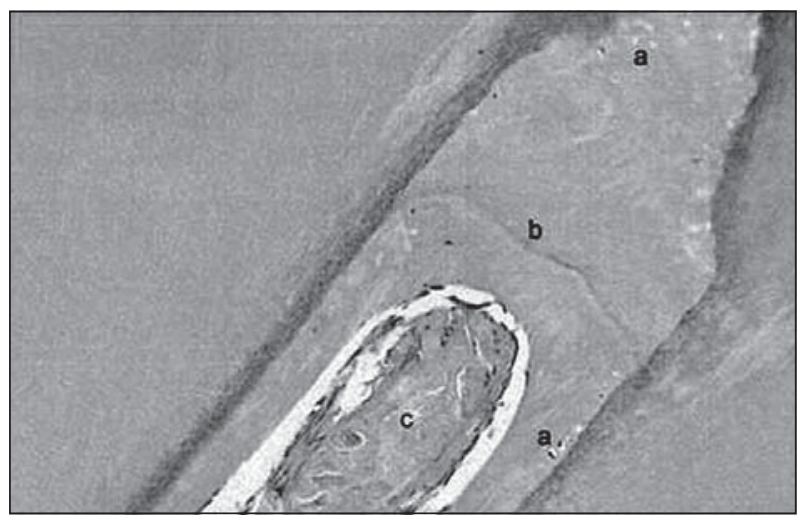

Figure 2. Thick dentinal bridge of irregular structure after use of MTA for pulpotomy in canine in the upper jaw: a) soft-tissue inclusions and defects in the form of tubules; b) calcichromatic line on the border between two periods of reparative dentin formation; c) osteoid-like formation within the root canal (original magnification $100 / 0.25,160 / 0.17$ )

Slika 2. Debeo dentinski most nepravilne strukture posle MTA pulpotomije očnjaka u gornjoj vilici: a) inkluzije i oštećenja mekog tkiva u obliku kanalića; b) kalciohromatična liniji na granici dva perioda stvaranja reparativnog dentina; c) formacija nalik osteoidu unutar kanala korena zuba (originalno uveličanje 100/0.25, 160/0.17) 
rials on surrounding cell culture. However, production of signaling molecules and ions should have an acceptable concentration in order to accelerate the cell viability and proliferation. Although the formation of hydroxyapatite is desirable and it is a sign of biocompatibility of materials, hydroxyapatite can sometimes cause cell death and slow down the cell proliferation if the concentration of Ca-P particles is high.

High concentration can influence osteoblastic activity. Zhao et al. [37] confirmed that the quantity of extracts from calcium silicate bioactive material should be at a desired concentration in order to accelerate the proliferation of cells. Some studies showed that direct application of MTA on pulp tissue caused proliferation, migration and differentiation of odontoblastic cells to produce collagen matrix. The matrix was mineralized and created osteodentin first while several months after pulp capping the bridge of tertiary dentin was formed (Figures 1 and 2). Mechanism of action of MTA is very similar to the effects of $\mathrm{Ca}(\mathrm{OH})_{2}$ after pulp capping $[35,36]$.

Thomson et al. [38] have shown that MTA releases a variety of signaling molecules from dentin powder, which also have an impact on the quality and speed of calcification of the bridge during its formation. Rapid bactericidal effect on Enterococcus faecalis was confirmed in some studies where the dentin powder was mixed with MTA powder. Cement-conductive and cement-inductive effect of MTA was also confirmed even with low concentration of material $(20 \mathrm{mg} / \mathrm{mL})$. Some studies showed that after surgical curettage of central giant cell granulomas MTA is acting as a catalyst when empty space after removing the granulomas is filled with this material. It also shows osteoconductive and osteoinductive effects and enhances the formation of bone in the tumor, even the suppresive effect on tumor recurrence is speculated [35, 36].

Based on available information, MTA is bioactive material which can create an ideal environment for healing surrounding tissue. In contact with human tissue, this material causes a series of processes such as: 1 ) formation of $\mathrm{Ca}(\mathrm{OH})_{2}$, which releases $\mathrm{Ca}^{2+}$ ions for cellular adhesion and proliferation; 2) antibacterial effect with its alkaline $\mathrm{pH} ; 3$ ) modulation of cytokine production; 4) boosting differentiation and migration of cells that produce hard tissues; 5) formation of hydroxyapatite (or carbonate apatite) on the surface of MTA, which allows its biological closure.

\section{DISADVANTAGES OF MTA}

The main disadvantage of MTA is related to its color, the presence of toxic elements in the composition, the difficulty of maintaining material properties over time, long time for networking, high cost, the absence of solvent for these materials and the difficulty of its removal after crosslinking.

Fe and $\mathrm{Mn}$ ions are responsible for the effects of staining. In addition, MTA also contain toxic elements such as Arsen (As), which is released very slowly. The presence of ferric oxide stabilizes As in MTA. Therefore, a small amount of ferric oxide is added to MTA in order to increase its insolubility and to control the kinetics of As release in tissue fluids, where it can become potentially toxic. Solubility of some Portland cements and the release of As from such materials makes them problematic for application [39]. MTA can be used as an alternative to gutta-percha for root canal obturation. The disadvantages are possible staining by MTA and long-time of networking. The high price of MTA and instruments required for the formation of apical barrier in teeth with necrotic pulp and immature roots as well as the handling problems are also significant disadvantages of this material. Long-time networking is one of the reasons that affect the use of this material. Also, none additive can cause faster networking of MTA. MTA also cannot be easily removed from the root canal when used as apical barrier or as material for root canal obturation. Efforts to overcome these problems by addition or removal of certain components influence the characteristics of MTA also, which makes improving the recipe for MTA very delicate $[34,39]$.

\section{CONCLUSION}

Based on numerous in vivo and in vitro studies it can be concluded that MTA is the material of choice for many indications in endodontics. This is primarily material for retrograde root canal obturation, root perforation, apical barrier forming in teeth with necrotic pulp and open apex, direct pulp capping and pulpotomy.

In all cases, it is confirmed that MTA quickly directs to the formation of hard tissue bridge.

Research related to the deposition of osteodentin, cell proliferation and the appearance of the immunoreactive odontoblast-like cells has shown that a thin layer of necrosis with inflammatory cells is formed first, around blood vessels of the pulp beneath the MTA. This necrotic layer is observed immediately after application (in some studies it was registered after one day) and after a few days the formation of calcified dentin bridge occurred.

Current research on materials designed for potential application in endodontics in several research groups suggests the potential of some new original recipes but also needs to confirm their superiority to MTA. Current studies that included cell lines and animals made us to believe that new materials with their characteristics could be comparable to MTA.

\section{REFERENCES}

1. Camilleri J, Pitt Ford TR. Mineral trioxide aggregate: a review of the constituents and biological properties of the material. Int Endod J. 2006; 39:747-54.

2. Roberts HW, Toth JM, Berzins DW, Charlton DG. Mineral trioxide aggregate material use in endodontic treatment: a review of the literature. Dent Mater. 2008; 24:149-64.

3. Andelin WE, Shabahang S, Wright K, Torabinejad M. Identification of hard tissue after experimental pulp capping using dentin sialoprotein (DSP) as a marker. J Endod. 2003; 29:646-50.

4. Parirokh $M$, Torabinejad $M$. Mineral trioxide aggregate: a 
comprehensive literature review - part I: chemical, physical and antibacterial properties. J Endod. 2010; 36:16-27.

5. Torabinejad M, Parirokh M. Mineral trioxide aggregate: a comprehensive literature review - part II: leakage and biocompatibility investigations. J Endod. 2010; 36:190-202.

6. Shayegan A, Petein M, Abbeele AV. The use of beta-tricalcium phosphate, white MTA, white Portland cement and calcium hydroxide for direct pulp capping of primary pig teeth. Dent Traumatol. 2009; 25:413-9.

7. Menezes R, Bramante CM, Letra A, Carvalho VG, Garcia RB. Histologic evaluation of pulpotomies in dog using two types of mineral trioxide aggregate and regular and white Portland cements as wound dressings. Oral Surg Oral Med Oral Pathol Oral Radiol Endod. 2004; 98:376-9.

8. Asgary S, Parirokh M, Eghbal MJ, Ghoddusi J, Eskandarizadeh A. SEM evaluation of neodentinal bridging after direct pulp protection with mineral trioxide aggregate. Endod J. 2006; 32:26-30.

9. Torabinejad M, Hong CU, Lee S), Monsef M, Pitt Ford TR. Investigation of mineral trioxide aggregate for root-end filling in dogs. J Endod. 1995; 21:603-8.

10. de Souza Costa CA, Duarte PT, de Souza PP, Giro EM, Hebling J. Cytotoxic effects and pulpal response caused by a mineral trioxide aggregate formulation and calcium hydroxide. Am J Dent. 2008; 21:255-61.

11. Bernabe PF, Holland R, Morandi R. Comparative study of MTA and other materials in retrofilling of pulpless dogs' teeth. Braz Dent J. 2005; 16:149-55.

12. Economides N, Pantelidou O, Kokkas A, Tziafas D. Short-term periradicular tissue response to mineral trioxide aggregate (MTA) as root-end filling material. Int Endod J. 2003; 36:44-8.

13. Ford TR, Torabinejad M, MCKendry DJ, Hong CU, Kariyawasam SP. Use of mineral trioxide aggregate for repair of furcal perforations. Oral Surg Oral Med Oral Pathol Oral Radiol Endod. 1995; 79:756-63.

14. Noetzel J, Ozer K, Reisshauer BH. Tissue responses to an experimental calcium phosphate cement and mineral trioxide aggregate as materials for furcation perforation repair: a histological study in dogs. Clin Oral Investig. 2006; 10:77.

15. Shabahang S, Torabinejad M, Boyne PP, Abedi H, McMillan P. A comparative study of root-end induction using osteogenic protein-1, calcium hydroxide, and mineral trioxide aggregate in dogs. J Endod. 1999; 25:1-5.

16. Felippe WT, Felippe MC, Rocha MJ. The effect of mineral trioxide aggregate on the apexification and periapical healing of teeth with incomplete root formation. Int Endod J. 2006; 39:2-9.

17. Ham KA, Witherspoon DE, Gutmann JL, Ravindranath S, Gait TC, Opperman LA. Preliminary evaluation of BMP-2 expression and histological characteristics during apexification with calcium hydroxide and mineral trioxide aggregate. J Endod. 2005; 31:275-9.

18. Holland R, Mazuqueli L, de Souza V, Murata SS, Dezan Junior E, Suzuki P. Influence of the type of vehicle and limit of obturation on apical and periapical tissue response in dogs' teeth after root canal filling with mineral trioxide aggregate. J Endod. 2007; 33:693-7.

19. Bortoluzzi EA, Broon NJ, Bramante CM, Consolaro A, Garcia RB, de Moraes IG, et al. Mineral trioxide aggregate with or without calcium chloride in pulpotomy. J Endod. 2008; 34:172-5.

20. Rubinstein R, Torabinejad M., Contemporary endodontic surgery. J Calif Dent Assoc. 2004; 32:485-92.

21. O'Sullivan SM, Hartwell GR. Obturation of a retained primary mandibular second molar using mineral trioxide aggregate: a case report. J Endod. 2001; 27:703-5.

22. Nair PN, Duncan HF, Pitt Ford TR, Luder HU. Histological, ultrastructural and quantitative investigations on the response of healthy human pulps to experimental capping with mineral trioxide aggregate: a randomized controlled trial. Int Endod J. 2008; 41:128-50.

23. Pace R, Giuliani V, Pagavino G. Mineral trioxide aggregate as repair material for furcal perforation: case series. J Endod. 2008; 34:1130-3.

24. El-Meligy OA, Avery DR. Comparison of apexification with mineral trioxide aggregate and calcium hydroxide. Pediatr Dent. 2006; 28:248-53.

25. Pace R, Giuliani V, Pini Prato L, Baccetti T, Pagavino G. Apical plug technique using mineral trioxide aggregate: results from a case series. Int Endod J. 2007; 40:478-84.

26. Hsien HC, Cheng YA, Lee YL, Lan WH, Lin CP. Repair of perforating internal resorption with mineral trioxide aggregate: a case report. J Endod. 2003; 29:538-9.

27. Qudeimat MA, Barrieshi-Nusair KM, Owais Al. Calcium hydroxide vs mineral trioxide aggregates for partial pulpotomy of permanent molars with deep caries. Eur Arch Paediatr Dent. 2007; 8:99-104.

28. Kim S, Kratchman S. Modern endodontic surgery concepts and practice: a review. J Endod. 2006; 32:601-23.

29. Saunders WP. A prospective clinical study of periradicular surgery using mineral trioxide aggregate as a root-end filling. J Endod. 2008; 34:660-5.

30. Meire M, De Moor R. Mineral trioxide aggregate repair of a perforating internal resorption in a mandibular molar.) Endod. 2008; 34:220-3.

31. Silveira FF, Nunes E, Soares JA, Ferreira CL, Rotstein I. Double 'pink tooth' associated with extensive internal root resorption after orthodontic treatment: a case report. Dent Traumatol. 2009; 25:43-7.

32. Mooney GC, North S. The current opinions and use of MTA for apical barrier formation of non-vital immature permanent incisors by consultants in paediatric dentistry in the UK. Dent Traumatol. 2008; 24:65-9.

33. Boutsioukis C, Noula G, Lambrianidis T. Ex vivo study of the efficiency of two techniques for the removal of mineral trioxide aggregate used as a root canal filling material. J Endod. 2008; 34:1239-42.

34. Sarkar NK, Caicedo R, Ritwik P, Moiseyeva R, Kawashima I. Physicochemical basis of the biologic properties of mineral trioxide aggregate. J Endod. 2005; 31:97-100.

35. Hakki SS, Bozkurt SB, Hakki EE, Belli S. Effects of mineral trioxide aggregate on cell survival, gene expression associated with mineralized tissues, and biomineralization of cementoblasts. J Endod. 2009; 35:513-9.

36. Takita T, Hayashi M, Takeichi O, Ogiso B, Suzuki N, Otsuka K, et al. Effect of mineral trioxide aggregate on proliferation of cultured human dental pulp cells. Int Endod J. 2006; 39:415.

37. Zhao W, Wang J, Zhai W, Wang Z, Chang J. The self-setting properties and in vitro bioactivity of tricalcium silicate. Biomaterials. 2005; 26:6113-21.

38. Tomson PL, Grover LM, Lumley PJ, Sloan AJ, Smith AJ, Cooper PR. Dissolution of bio-active dentine matrix components by mineral trioxide aggregate. J Dent. 2007; 35:636-42.

39. Glickman GN, Koch KA. 21st-century endodontics. J Am Dent Assoc. 2000; 131(Suppl):39S-46S.

Received: 25/01/2011 • Accepted: 15/04/2011 


\title{
Mineral trioksid-agregat kao materijal izbora u endodonciji
}

\author{
Vukoman Jokanović ${ }^{1}$, Božana Čolović1, Slavoljub Živković2 , Vesna Živojinović3, Dejan Marković3 \\ 'Laboratorija za radijacionu fiziku i hemiju, Institut nuklearnih nauka „Vinča”, Beograd, Srbija; \\ 2Klinika za bolesti zuba, Stomatološki fakultet, Univerzitet u Beogradu, Beograd, Srbija; \\ ${ }^{3}$ Klinika za dečju i preventivnu stomatologiju, Stomatološki fakultet, Univerzitet u Beogradu, Beograd, Srbija
}

\begin{abstract}
KRATAK SADRŽAJ
Mineral trioksid-agregat (MTA) je materijal koji ima široke indikacije u endodonciji. Danas se koristi kod prekrivanja vitalne pulpe i pulpotomije, kao apeksna barijera kod zuba s nekrotičnom pulpom i otvorenim apeksom korena, odnosno u lečenju različitih perforacija kanala korena. Poređenja biološkog odgovora tkiva pulpe prekrivene kalcijum-hidroksidom i MTA ukazuju na superiornost MTA, jer se formira most tvrdog tkiva koji sprečava iritaciju pulpe. Histološke studije pulpotomija na zubima pasa pokazale su da se ispod MTA stvara tvrdo koštano tkivo bez nekroze posle 120 dana. MTA je takođe materijal izbora za retrogradno punjenje kanala korena, odnosno za terapiju lateralnih perforacija. Metaanaliza publikovanih radova o MTA poslednjih godina ukazuje na veliki klinički uspeh ovog materijala, koji obezbeđuje dobro zaptivanje, pokazuje superiornu biokompatibilnost i jedini je materijal za retrogradno punjenje kanala korena zuba koji pospešuje regeneraciju tkiva. Istraživanja takođe pokazuju da MTA ima induktivna i konduktivna svojstva za formiranje tvrdog tkiva, kao i osobinu otpuštanja različitih jona kada se nalazi u tečnoj sredini. Glavni nedostatak MTA je u vezi sa bojom zbog prisustva gvožđa i mangana, sa teškoćama održavanja osobina materijala tokom vremena, sa izostankom rastvarača za ovaj materijal i sa teškoćama njegovog uklanjanja posle umrežavanja.
\end{abstract}

Ključne reči: mineral trioksid-agregat (MTA); direktno prekrivanje pulpe; retrogradna hirurgija; klinička primena

\section{UVOD}

Mineral trioksid-agregat (MTA) je materijal koji ima široke indikacije u endodonciji. Koristi se u lečenju različitih perforacija kanala korena, kod pulpotomija i prekrivanja vitalne pulpe, kao apeksna barijera kod zuba s nekrotičnom pulpom i otvorenim apeksom korena. MTA u kontaktu sa simuliranim telesnim tečnostima dovodi do stvaranja hidroksiapatitnih kristala, što je osnov za formiranje kalcifikovanih struktura prilikom primene ovog materijala $[1,2]$.

MTA je razvijen kao materijal za prekrivanje pulpe, kao sredstvo koje se koristi kod pulpotomija, odnosno kao materijal za stvaranje apeksne barijere kod zuba sa nezavršenim rastom korena, i kao materijal za retrogradno punjenje kanala korena. Studije na eksperimentalnim životinjama (model mlečnih zuba svinje) u kojima je ispitan tretman vitalne pulpe u kojima su korišćeni MTA, beta-trikalcijum-fosfat i „portland” cement pokazale su da nema značajnijih razlika u odgovoru pulpe na primenu ovih materijala.

Kod stalnih zuba rađena su brojna istraživanja direktnog prekrivanja pulpe sa ciljem da se procene formiranje, kvalitet i debljina kalcifikovanog mosta, zastupljenost inflamatornih ćelija i efikasnost zaštite pulpe, kao bitnih kriterijuma za procenu vitalnosti pulpe posle terapije. Histološka istraživanja u kojim su poređeni MTA i kalcijum-hidroksid $\left(\mathrm{Ca}(\mathrm{OH})_{2}\right)$, kao materijali za direktno prekrivanje pulpe, ukazala su na bitne razlike. Nakon primene MTA pojava kalcifikovanog mosta je uočena već nakon prve nedelje. Pulpa nije bila upaljena i u svim slučajevima je posle pet meseci došlo do stvaranja kalcifikovanog mosta. Nasuprot tome, kod pulpi prekrivenih sa $\mathrm{Ca}(\mathrm{OH})_{2}$ uočeni su zapaljenje i značajno manji stepen formiranja kalcifikovanog mosta. U eksperimentima na psima utvrđeno je da posle prekrivanja pulpe sa MTA dolazi do stvaranja osteodentinske strukture posle samo dve nedelje. Nastajanje ovog mosta odvija se u dve faze. Tokom prve dve nedelje formira se matrica osteodentina, da bi se posle tri nedelje stvorio kompletan sloj reparativnog dentina. U drugim istraživanjima na zubima pasa bolji rezultati su dobijeni nakon prekrivanja pulpe, MTA u odnosu na preparate na bazi $\mathrm{Ca}(\mathrm{OH})_{2}[1,2]$.

$\mathrm{U}$ studiji na maksilarnim molarima miša Andelin (Andelin) i saradnici [3] su upoređivali MTA sa koštanim morfogenetskim proteinom -7 (BMP-7) kao materijalom za prekrivanje pulpe. Uzorci su imunohistometrijski bojeni, kako bi se prepoznao dentinski sijaloprotein (DSP) markerom za funkcionalne odontoblaste. Posle dve nedelje kod svih zuba prekrivenih sa MTA uočeno je stvaranje tvrdog tkiva koje je bilo vrlo slično tercijarnom dentinu.

Poređenja biološkog odgovora tkiva pulpe prekrivene sa $\mathrm{Ca}(\mathrm{OH})_{2}$ i MTA ukazuju na superiornost MTA, jer se stvara most tvrdog tkiva koji sprečava iritaciju pulpe. Rezultati istraživanja depozicije osteodentina, ćelijske proliferacije i izgleda imunoreaktivnih ćelija sličnih odontoblastima pokazuju da se prvo formira tanki nekrotični sloj s inflamatornim ćelijama (posle prvog dana), a zatim, posle sedam dana, dolazi do stvaranja kalcifikovanog mosta. Druga studija na maksilarnim molarima miša ukazala je na postojanje kalcifikovanog mosta u svim uzorcima pet sati posle prekrivanja pulpe. Kod mehanički eksponiranih pulpi pacova s hiperglikemijom uočeni su veći stepen zapaljenja i sporije formiranje dentinskog mosta u odnosu na normalne pacove nakon prekrivanja pulpe sa MTA. SEM i TEM studije na psima su takođe jasno ukazale na formiranje kristalne strukture nedelju dana posle prekrivanja pulpe $[4,5]$.

Koristeći EDS analizu istraživači su utvrdili da se ispod MTA nalazi manja količina kalcijuma nego u prethodno formiranom ortodentinu. Ova istraživanja pokazuju da se kalcifikovani most uglavnom sastoji od kalcijuma i fosfora, iako je MTA uglavnom sastavljen od kalcijuma i silicijuma.

Istraživanja efekata pulpotomije i primene pet različitih agensa koje su izveli Šejegan (Shayegan) i saradnici [6] na mlečnim zubima svinje pokazala su značajne prednosti MTA sa stanovišta inflamacije, formiranja kalcifikovanog mosta i zaštite preostale zubne pulpe u odnosu na formokrezol (FC), jedinjenje koje sadrži formaldehid, krezol, glicerin, vodu i ferisulfat. Histološke studije pulpotomija na stalnim zubima pacova i miševa, 
u kojima su poređeni MTA, $\mathrm{PC}, \mathrm{Ca}(\mathrm{OH})_{2}$, bioaktivno staklo i ferisulfat, pokazale su slične rezultate za MTA i PC. Slična istraživanja na maksilarnim molarima pacova ukazala su na to da se kod pulpotomija prekrivenih sa MTA formiranje potpunog dentinskog mosta uočava već posle četiri nedelje. Kod pulpotomija na zubima pasa ispod MTA je formirano tvrdo koštano tkivo bez nekroze pulpe posle 120 dana [7]. U poređenju sa $\mathrm{Ca}(\mathrm{OH})_{2}$, kod MTA je uočen mnogo manji gubitak zdravog tkiva pulpe, što se pripisuje većim početnim vrednostima $\mathrm{pH}$, odnosno lošijim zaptivanjem pulpe preparatima na bazi $\mathrm{Ca}(\mathrm{OH})_{2}$. Ispod $\mathrm{Ca}(\mathrm{OH})_{2}$ su uočeni izostanak tvrde barijere i blago zapaljenje pulpnog tkiva.

SEM istraživanja i analiza pomoću rendgenskih zraka pokazala su da je kalcifikovana barijera ispod MTA tubularnije građe nego ispod $\mathrm{Ca}(\mathrm{OH})_{2}$ i $\mathrm{AEDB}[3,4,5,8]$.

\section{MTA KAO MATERIJAL ZA RETROGRADNO PUNJENJE KANALA KORENA ZUBA}

Prvo istraživanje u kojem je MTA korišćen kao materijal za retrogradno punjenje kanala korena zuba kod pasa izveli su Torabinedžad (Torabinejad) i saradnici [9]. Oni su pokazali da MTA pospešuje stvaranje cementa u $23 \%$ ispitivanih uzoraka nakon 2-5 nedelja, a u više od $80 \%$ slučajeva formiranje cementa je uočeno 10-18 nedelja nakon periapeksnog hirurškog lečenja. Nasuprot tome, nijedno retrogradno punjenje amalgamom nije pokazalo depoziciju cementa. Poređenjem MTA s amalgamom SuperEBA (SuperEBA je cement na bazi cink-oksid eugenola, koji se sastoji od 32\% eugenola i $68 \%$ etoksi-benzolne kiseline) utvrđeno je da MTA pokazuje bolje rezultate $\mathrm{u}$ pogledu polimorfonuklearne infiltracije, sazrevanja kosti i formiranja cementa $[7,10]$.

Nasuprot ovim histološkim nalazima, Bernabi (Bernabe) i saradnici [11] su ustanovili beznačajnu razliku između korišćenih materijala 180 dana posle hirurškog zahvata na avitalnim zubima. Pri tome, ZOE (cink-oksid eugenol) je imao značajno lošiji uticaj na apeksno zaceljivanje nego drugi ispitivani materijali. MTA je jedini pokazao depoziciju tvrdog tkiva u direktnom kontaktu s materijalom za punjenje kanala korena zuba [12].

\section{MTA KAO MATERIJAL ZA TERAPIJU LATERALNIH PERFORACIJA}

Ford (Ford) i saradnici [13] su prvi koristili MTA u lečenju od lateralnih perforacija. Pokazali su da je, za razliku od amalgama, ispod MTA kod većine tretiranih zuba došlo do formiranja cementa. Uočeno je takođe da kod nelečenih perforacija dolazi do kontaminacije i da je tada efekat MTA znatno usmanjen. U poređenju sa SuperEBA, gde nije došlo do stvaranja cementa ni posle šest meseci, u svim uzorcima sa MTA zapaženo je formiranje cementa. U studiji Necela (Noetzel) i saradnika [14] dobijen je sličan rezultat. Pri poređenju MTA sa trikalcijum-fosfatnim cementima uočeno je da MTA pokazuje znatno manju inflamaciju i bolje formiranje kosti $[9,11]$.

Na osnovu velikog broja istraživanja u kojima je MTA poređen sa drugim materijalima za reparaciju perforacija, potvrđeno je da MTA daje najbolje histološke rezultate. Rezultati sa MTA su bili znatno bolji u poređenju sa silpeksom (Sealpex).
Kod uzoraka sa MTA posle 180 dana došlo je do stvaranja cementa i nije bilo znakova zapaljenja $[9,11]$.

\section{MTA KAO APEKSNA BARIJERA ZUBA S NEKROTIČNOM PULPOM I NEZAVRŠENIM RASTOM KORENA}

Šabahang (Shabahang) i saradnici [15] su u svojim istraživanjima na zubima pasa s nezavršenim rastom korena izazvali perapeksne lezije i zatim koristili osteogeni protein 1, MTA i $\mathrm{Ca}(\mathrm{OH})_{2}$ kao apeksnu barijeru. Kod zuba sa MTA uočeni su veća učestalost apeksnog zatvaranja i znatno slabije zapaljenje nego kod druge dve grupe. S druge strane, u eksperimentu na zubima majmuna s inficiranim kanalom korena i otvorenim apeksom zapažene su značajne prednosti MTA u odnosu na $\mathrm{Ca}(\mathrm{OH})_{2}$. Posle 90 dana od opturacije, kanali ispunjeni sa MTA su imali veće količine tvrdo formiranog tkiva i najslabije zapaljenje. Rezultati Felipea (Felippe) i saradnika [16] u sličnim istraživanjima pokazali su da između MTA i Ca(OH $)_{2}$ nema velike razlike kod zuba s nezavršenim rastom i inflamiranim, odnosno neinflamiranim kanalima, u pogledu formiranja apeksne barijere, koštane resorpcije zastupljenosti mikroorganizama. Ovakve studije su pokazale da se MTA može koristiti kao apeksna barijera i kod zuba s nekrotičnom pulpom i otvorenim apeksom bez prethodnog tretmana sa $\mathrm{Ca}(\mathrm{OH})_{2}$ $[13,14,15,17]$.

\section{MTA KAO MATERIJAL ZA OPTURACIJU KANALA KORENA ZUBA}

Holand (Holland) i saradnici [18] su upoređivali glasjonomercement (GJC) za opturaciju kanala (Ketac-Endo) sa MTA na zubima pasa. Rezultati njihovog istraživanja su pokazali da šest meseci posle opturacije kanala sa MTA dolazi do konzistentnog zatvaranja glavnog kanala, stvaranja novog cementa i izostanka inflamatornih ćelija. Nasuprot tome, GJC je pokazao samo delimično zatvaranje glavnog kanala i blagu inflamatornu reakciju oko vrha korena. Ovi autori su takođe ispitivali uticaj kvaliteta opturacije i odgovor apeksnog i periapeksnog tkiva posle punjenja kanala korena sa MTA. Istraživanja su pokazala da se MTA može koristiti za opturaciju, ali da prebacivanje paste može imati i štetne efekte na periapeksna tkiva [16].

\section{ISPITIVANJE DRUGIH TIPOVA MTA NA ŽIVOTINJAMA}

Angelus MTA (AMTA) je drugi tip MTA, a sastoji se od $\mathrm{SiO}_{2}$, $\mathrm{K}_{2} \mathrm{O}, \mathrm{Al}_{2} \mathrm{O}_{3}, \mathrm{Na}_{2} \mathrm{O}, \mathrm{Fe}_{2} \mathrm{O}_{3}, \mathrm{SO}_{3}, \mathrm{CaO}, \mathrm{Bi}_{2} \mathrm{O}_{3}$ i $\mathrm{MgO}$. Poređenjem efekata MTA i AMTA kod pulpotomija na zubima pasa uočeno je formiranje kalcifikovanog mosta kod oba materijala. Ipak, u poređenju sa $\mathrm{Ca}(\mathrm{OH})_{2}$, posle 180 dana razlike nisu bile bitne. Holand i saradnici [18] su smesu MTA sa polipropilenom ili destilovanom vodom koristili kao materijal za punjenje kanala korena zuba pasa. Praćen je i efekat prepunjavanja kanala MTA. Obe smese su pokazale slične biološke odgovore, ali su bolji rezultati kod MTA uočeni kod opturacije kanala korena. Bortoluci (Bortoluzzi) i saradnici [19] su uporedili smesu MTA praha sa desetoprocentnim $\mathrm{CaCl}_{2}$ ili destilovanom vodom kod 
pulpotomija zuba pasa. Posle 90 dana oba materijala su pokazala dobre rezultate u pogledu stvaranja tvrdog tkiva, ali su uočeni i umereno hronično zapaljenje i angioblastna proliferacija [16].

\section{KLINIČKA PRIMENA MTA}

Klinička ispitivanja materijala su najbitnija za procenu njihove efikasnosti i podobnosti za primenu. MTA je jedan od materijala izbora za retrogradnu opturaciju kanala korena zuba, za prekrivanje pulpe, pulpotomiju, formiranje apeksne barijere kod zuba s nekrotičnom pulpom i otvorenim apeksom, terapiju perforacija i apeksfiksaciju. Nekoliko radova se bavilo primenom MTA kao materijala za prekrivanje pulpe i potvrđeno je da je ovaj materijal veoma efikasan u lečenju od pulpotomija $[18,20]$.

U mnogim kliničkim studijama je pokazano da se MTA može uspešno primeniti za prekrivanje pulpe mlečnih molara (radiografski uspeh posle 24 meseca uočen je i kod MTA i kod $\left.\mathrm{Ca}(\mathrm{OH})_{2}\right)$. Primena MTA kod pulpotomija je znatno efikasnija od primene formokrezola (FC) ili formokrezola pomešanog sa $\mathrm{ZnO}$ i eugenolom, odnosno kod primene diodnih lasera. Posle 12 meseci klinička, radiografska i histološka istraživanja su pokazala bolje dejstvo MTA u odnosu na FC.

U kliničkom izveštaju O'Salivena (O'Sullivan) i Hartvela (Hartwell) [21] potvrđena je efikasnost MTA kao materijala za opturaciju primarnih molara. Ispitivanja u studiji ex vivo izvedena su tako što je treći molar čoveka s nezavršenim rastom neposredno nakon vađenja ubačen u medijum ćelijske kulture, a zatim je eksponirana pulpa prekrivena sa MTA ili $\mathrm{Ca}(\mathrm{OH})_{2}$. Imunohistohemijska analiza pulpe prekrivene sa MTA ukazala je na mineralizaciju već posle jednog dana, dok kod pulpe prekrivene sa $\mathrm{Ca}(\mathrm{OH})_{2}$ mineralizacija nije uočena. Međutim, nakon 14 i 28 dana u obe grupe uzoraka uočen je sličan stepen mineralizacije. U vidu studija in vivo publikovano je nekoliko radova u vezi s korišćenjem MTA [20, 21, 22].

U istraživanju 14 intaktnih trećih maksilarnih molara (koje je bilo potrebno izvaditi) eksponirana pulpa je prekrivena sa MTA ili $\mathrm{Ca}(\mathrm{OH})_{2}$. Histološka analiza ovih zuba u različitim vremenskim intervalima ukazala je na stvaranje dentalnog mosta i blago hronično zapaljenje nakon dva meseca. Na uzorcima prekrivenim sa $\mathrm{Ca}(\mathrm{OH})_{2}$ posle tri meseca uočeni su tanki i nepravilni dentinski mostovi, nekroza pulpe, hipermija i zapaljenje. Autori su zaključili da je za tretman mehanički eksponirane pulpe MTA bolji materijal nego $\mathrm{Ca}(\mathrm{OH})_{2}$. Klinička istraživanja primene MTA i $\mathrm{Ca}(\mathrm{OH})_{2}$ na humanim trećim molarima bez karijesa otkrila su velike razlike u pogledu kliničkih simptoma, površinskih i dubinskih inflamatornih ćelija, vitalnosti pulpe i formiranja dentinskog mosta. Kod molara s reverzibilnim pulpitisom prekrivenih sa MTA tretman je bio uspešan u 93\% slučajeva nakon 24 meseca. Kod svih uzoraka došlo je do formiranja dentinskog mosta, dok se među uzorcima prekrivenim sa $\mathrm{Ca}(\mathrm{OH})_{2}$ dentinski most formirao u samo $60 \%$ slučajeva. Histološka analiza je pokazala da kod uzoraka sa MTA posle prve nedelje nije bilo zapaljenja, a već posle prvog meseca je bilo formirano kompletno tvrdo tkivo. Tkivo ispod $\mathrm{Ca}(\mathrm{OH})_{2}$ je bilo manje konzistentno i čvrsto i sa nepotpunim kalcifikovanim mostom, uz akutno zapaljenje čak i posle tri meseca [23-26].

$\mathrm{U}$ svim istraživanjima primene $\mathrm{Ca}(\mathrm{OH})_{2}$ utvrđeno je mnogo veće zapaljenje nego kada je korišćen MTA za prekrivanje pulpe. Kudima (Qudeimat) i saradnici [27] su proučavali efekat materijala na 28 zuba zahvaćenih karijesom. Postupak se sastojao od uklanjanja karijesa i 2-4 mm pulpe iz kanala i potom prekrivanja ostatka pulpe sa MTA. Normalan odgovor na testove vitalnosti pokazalo je 79\% zuba [23-26]. Od 23 zuba sa simptomima punjenim sa MTA kod samo jednog je registrovan stalni bol. Zato se smatra da je korišćenje MTA kod pulpotomija stalnih zuba opravdano.

U preglednom radu u kojem su izložili koncept moderne ondodonske hirurgije, Kim (Kim) i Kračman (Kratchman) [28] su pokazali da je MTA najbiokompatibilniji materijal za retrogradno punjenje kanala korena zuba i da se može predložiti kao izuzetno kvalitetno rešenje u endodontskoj hirurgiji. Interesantan pristup daje i studija Sandersa (Saunders) [29], koji je kombinovao endodontski i periodontalni pristup u lečenju primenom MTA. U studiji sa 276 zuba retrogradno punjenim sa MTA klinički i radiografski uspeh postignut je u $88,8 \%$ slučajeva već posle 4-72 meseca.

Metaanaliza 30 radova objavljenih poslednjih godina upućuje na veliki klinički uspeh MTA, koji obezbeđuje dobro zaptivanje, pokazuje superiornu biokompatibilnost i jedini je materijal za retrogradno punjenje kanala (u odnosu na amalgam, ZOE i SuperEBA) koji pospešuje regeneraciju tkiva. Neke studije pokazuju da je MTA moguće koristiti i u terapiji lateralnih perforacija $[26,30,31,32]$. U periodu od šest do dvanaest meseci kod zuba s lateralnim perforacijama u $82 \%$ slučaja dolazi do uspešnog izlečenja posle primene MTA.

Da bi se prevenirala ekstruzija, kao jedan od nedostataka MTA, neki autori predlažu dodavanje kolagena. Tretman zuba s nezavršenim rastom i nekrotičnom pulpom poseban je izazov za stomatologe. Formiranje apeksne barijere sa MTA je mnogo brže nego sa $\mathrm{Ca}(\mathrm{OH})_{2}$. Primena MTA je ukazala na značajan uspeh u tretmanu nekrotične pulpe zuba s nezavršenim rastom korena (u 81-94,1\% slučajeva). Na uspešnost procedure nisu uticali starost i pol ispitanika, početni tretman, postojanje periapeksnih lezija, niti vreme proteklo od tretmana [32, 33].

Statistika pokazuje da $86,3 \%$ dečjih stomatologa smatra da je tretman sekutića s nezavršenim rastom i nekrotičnom pulpom sa MTA prihvatljiva metoda jer obezbeđuje regenerativni potencijal pulpe.

U nekoliko kliničkih studija na mlečnim i stalnim zubima potvrđeno je uspešno hirurško i nehirurško lečenje zuba sa spoljašnjim i unutrašnjim resorpcijama oštećenja primenom MTA. Ovaj materijal se pokazao veoma delotvornim kod tretmana lateralnih perforacija, horizontalnih preloma, punjenja kanala korena zuba, tretmana zuba s nezavršenim rastom, odnosno tretmana unutrašnjih i spoljašnjih resorpcija korena [26, 30-33].

\section{MEHANIZAM DELOVANJA MTA}

Jedna od odlika bioaktivnih materijala je sposobnost da na svojoj površini formiraju strukture slične apatitu kada dođu u kontakt $s$ fizološkom tečnošću in vivo ili sa simuliranom telesnom tečnošću in vitro. Stvaranje apatita je zajednička osobina biomaterijala koji sadrže kalcijum-silikate. MTA je bioaktivni materijal koji se uglavnom sastoji od kalcijuma i silikata. Istraživanja pokazuju da on ima konduktivna i induktivna svojstva za formiranje tvrdog tkiva. Istovremeno, mnoga istraživanja pokazuju i otpuštanje različitih jona iz MTA kada se nalazi u tečnoj sredini. 
U jednom eksperimentu Sarkar (Sarkar) i saradnici [34] su punili kanale korena zuba sa MTA i čuvali ih u PBS dva meseca uz stalno posmatranje otpuštanja jona $\mathrm{Ca}, \mathrm{Si}, \mathrm{Bi}, \mathrm{Fe}, \mathrm{Al}$ i Mg. Optička i SEM mikroskopija nakon resekcije vrhova korena otkrile su postojanje sloja između MTA i zidova kanala korena. Istraživanja ove strukture primenom EDS pokazala su da se ovaj sloj sastoji od atoma Ca, P i O, te da je vrlo sličan hidroksiapatitu. Autori smatraju da hidroksiapatit može neprestano da otpušta jone $\mathrm{Ca}$ i $\mathrm{PO}_{4}{ }^{3-}$ slično procesu tipičnom za metabolizam kosti. Ovaj fenomen takođe povećava sposobnost zaptivanja MTA i pospešuje regeneraciju i remineralizaciju tvrdih tkiva. Na osnovu ovakvih rezultata ukazano je na to da su biokompatibilnost, sposobnost zaptivanja i dentinogenska aktivnost MTA posledica fizičkohemijskih reakcija između MTA i telesnih tečnosti tokom stvaranja hidroksiapatita $[35,36]$.

Mnoga istraživanja na eksperimentalnim životinjama potvrdila su da je tvrda struktura nastala između međupovršine pulpe i MTA u stvari komponenta hidroksiapatita. Pokazano je takođe da se mala količina silicijuma i fosfora nalazi u kristalima MTA. Poroznost MTA je mogući nedostatak MTA, jer može da dovede do prodiranja bakterija i njihovih metaboličkih proizvoda. Formiranje ovoga sloja obezbeđuje hemijsku vezu MTA i dentinskog zida, i može biti ključna odlika ovog materijala. Sadašnja istraživanja pokazuju da se karbonatni hidroksiapatit formira preko MTA, pokazujući bioaktivnost MTA materijala. Karbonatni hidroksiapatit predstavlja mineralnu fazu tvrdog tkiva, kao što su kost, cementum i dentin, a poznat je pod imenom „biološki apatit“. Hidroksiapatit se formira na MTA već nakon prvog sata, da bi ga potpuno prekrio posle pet dana.

Prema rezultatima istraživanjima, formiranje apatitnih kristala unutar kolagenskih vlakana potpomaže reakciju između MTA i dentina, gradeći odgovarajuću hemijsku vezu. Koncentracija faktora rasta takođe igra značajnu ulogu u stvaranju tvrdog tkiva. Na primer, visoka koncentracija TGF- $\beta 1$ ima za rezultat apoptozu i snižavanje dentinskog fosfosialoproteina pre nego pozitivan efekat na ozdravljenje tkiva. Pojedini istraživači pretpostavljaju da stvaranje TGF- $\beta 1$ predstavlja pozitivan efekat kod bioaktivnog materijala na okolne ćelijske kulture. Međutim, stvaranje signalnih molekula i jona treba da ima neku prihvatljivu koncentraciju, da bi se pospešila vijabilnost i proliferacija ćelija. Iako je formiranje hidroksiapatita poželjno i siguran je znak biokompatibilnosti materijala, hidroksiapatit ponekad može izazvati ćelijsku smrt i usporiti proliferaciju ćelija ukoliko je koncentracija Ca-P čestica visoka.

Visoka koncentracija utiče na smanjenje aktivnosti osteoblasta. Žao (Zhao) i saradnici [37] su potvrdili da količina ekstrakata iz kalcijum-silikatnog bioaktivnog materijala treba da bude na nekoj željenoj koncentraciji da bi se pospešila proliferacija ćelija. Neka ispitivanja pokazuju da direktna primena MTA na tkivo pulpe izaziva proliferaciju, migraciju i diferencijaciju odontoblastnih ćelija koje proizvode kolagenski matriks. Formirani matriks se potom mineralizuje i stvara prvo osteodentin, a potom i most tercijarnog dentina nakon nekoliko meseci od prekrivanja pulpe (Slika 1). Mehanizam delovanja MTA je vrlo sličan efektu $\mathrm{Ca}(\mathrm{OH})_{2}$ na pulpu nakon prekrivanja $[35,36]$.

Tomson (Tomson) i saradnici [38] su pokazali da MTA otpušta različite signalne molekule iz dentinskog praha, koji takođe mogu imati uticaja na kvalitet i brzinu kalcifikacije mosta tokom njegovog formiranja. Brzo baktericidno dejstvo na Enterococcus faecalis potvrđen je u nekim istraživanjima gde je dentinski prah pomešan sa MTA prahom. Cemento-konduktivni i cementno-induktivni efekat MTA je potvrđen i pri manjoj koncentraciji materijala (od $20 \mathrm{mg} / \mathrm{ml}$ ). Pojedini radovi pokazuju da MTA posle hirurške kiretaže ima funkciju katalizatora kojim se pune šupljine centralnih gigantskih ćelijskih granuloma, pri čemu dolazi do osteokonduktivnih i osteoinduktivnih efekata, poboljšava se stvaranje kosti na mestima tumora i čak sprečava ponovna pojava tumora $[35,36]$.

Na osnovu nalaza istraživanja može se reći da je MTA bioaktivni materijal koji može da kreira idealnu okolinu za izlečenje okolnih tkiva. U kontaktu s ljudskim tkivom ovaj materijal uslovljava niz procesa, kao što su: 1) nastajanje $\mathrm{Ca}(\mathrm{OH})_{2}$, koji otpušta jone $\mathrm{Ca}^{2+}$ za ćelijsku adherenciju i proliferaciju; 2) antibakterijski efekat svojim alkalnim $\mathrm{pH}$; 3) modulacija proizvodnje citokina; 4) pospešivanje diferencijacije i migracije ćelija koje proizvode tvrda tkiva; 5) formiranje hidroksiapatita (ili karbonatnog apatita) na površini MTA, koji omogućuje njegovo biološko zatvaranje.

\section{NEDOSTACI MTA}

Glavni nedostaci MTA su: boja, zastupljenost toksičnih elemenata u sastavu, teškoće održavanja osobina materijala tokom vremena, dugo vreme umrežavanja, visoka cena, nepostojanje rastvarača za ove materijale i teškoće njegovog uklanjanja posle umrežavanja.

Gvožđe i mangan su odgovorni za efekte bojenja. Pored toga, MTA sadrži u sebi toksične elemente poput arsena, koji se otpušta vrlo sporo. Zastupljenost ferioksida stabilizuje arsen $u$ MTA. Zbog toga se u materijal unose male primese ferioksida, kako bi se povećala nerastvorljivost i mogla kontrolisati kinetika otpuštanja arsena u tkivne tečnosti, gde postaje potencijalno toksičan. Rastvorljivost nekih „portland” cementa i otpuštanje arsena iz takvih materijala čini ih problematičnim za primenu [39]. MTA se može koristiti i kao alternativa za gutaperku kod opturacije kanala korena zuba. Nedostaci su moguće bojenje MTA i dugo vreme umrežavanja. Visoka cena MTA i instrumenata potrebnih za stvaranje apeksne barijere kod zuba sa nekrotičnom pulpom i nezavršenim rastom korena i problemi pri rukovanju takođe su značajni nedostaci ovog materijala. Dugo vreme umrežavanja jedan je od razloga koji utiču na efikasnost primene materijala. Takođe, još nije pronađen odgovarajući aditiv za brže umrežavanje MTA. MTA se ne može lako ukloniti iz kanala kada se koristi kao apeksna barijera ili kao materijal za punjenje kanala korena. Napori da se prevaziđu ovi problemi dodatkom ili uklanjanjem određenih komponenti utiču i na osobine MTA, što problem unapređenja recepture MTA čini vrlo delikatnim [34, 39].

\section{ZAKLJUČAK}

Na osnovu brojnih istraživanja in vivo i in vitro može se reći da je MTA materijal izbora u raznim indikacijama u endodonciji. To je, pre svega, sredstvo za retrogradno punjenje kanala korena zuba, preparaciju perforacija, formiranje apeksne barijere zuba s nekrotičnom pulpom i otvorenim apeksom, direktno prekrivanje pulpe i lečenje od pulpotomija. On veoma brzo dovodi do stvaranja mosta tvrdog tkiva, koji predstavlja dobru zaštitu. 
Istraživanja u vezi sa depozicijom osteodentina, ćelijskom proliferacijom i izgledom osnove imunoreaktivnih odontoblasta sličnih ćelija pokazala su da se oko krvnih sudova pulpe prvo formira tanak nekrotični sloj sa inflamiranim ćelijama ispod MTA. Ovaj nekrotični sloj se uočava odmah nakon primene (u nekim istraživanjima je uočen već posle 24 sata), a posle nekoliko dana dolazi do formiranja kalcifikovanog dentinskog mosta.
Trenutna istraživanja na materijalima dizajniranim za potencijalnu primenu u endodonciji u okviru nekoliko istraživačkih grupa treba da ukažu na potencijal nekih novih originalnih receptura, ali i da u odnosu na MTA kao materijal izbora potvrde svoje kvalitete. Dosadašnji rezultati na ćelijskim linijama i eksperimentalnim životinjama daju za pravo da verujemo da će novi materijali sa svojim svojstvima moći da se porede sa MTA. 